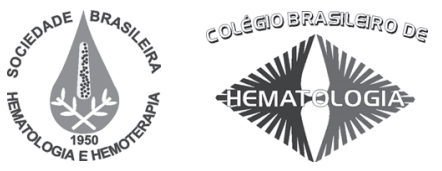

\title{
Influência de polimorfismos genéticos sobre a atividade da enzima hidroximetilbilano sintase
}

\section{Influence of genetic polymorphisms on hydroxymethylbilane synthase enzyme activity}

Ana D. G. Gonzaga
Orientadora: Georgina S. Ribeiro

\section{Resumo}

A enzima hidroximetilbilano sintase (HMBS) catalisa a terceira etapa da biossíntese do grupamento heme. Mutações no gene que codifica esta enzima resultam em redução parcial da sua atividade, ocasionando a porfiria aguda intermitente (PAI), uma doença de herança autossômica dominante. O presente trabalho teve como objetivo investigar se os polimorfismos genéticos C2377A (ApaL I), A2478G (BstN I), G1345A (Msp I) e T1500C (Pst I) no intron 1; A3581G (BsmA I) no intron 3 e C7064A (Hinf I), no intron 10 do gene, contribuíram para a redução da atividade enzima HMBS. Foram incluídos 80 doadores de sangue e 124 membros de quatro famílias com histórico de PAI (famílias D, S, B e SP). Anteriormente, o DNA genômico foi isolado de amostras de sangue total pelo método de precipitação salina e a avaliação da atividade enzimática no hemolisado foi quantificada por espectrofotometria e/ou por espectrofluorimetria. Os indivíduos foram classificados em deficientes e não deficientes de acordo com os valores de referência estabelecidos nestes métodos. As famílias com histórico de PAI tiveram a mutação definida por PCR-SSCP e sequenciamento em estudo anterior. Os polimorfismos genéticos foram avaliados por PCR-RFLP. Houve diferença significativa na distribuição alélica dos polimorfismos entre famílias e doadores voluntários. A distribuição genotípica dos polimorfismos C2377A, A2478G, G1345A, A3581G e C7064A em famílias com histórico de PAI foi significativamente diferente da distribuição encontrada para os doadores de sangue, indicando que estes polimorfismos podem ser considerados marcadores genéticos para estas famílias. O alelo A do polimorfismo C7064A apresentou a frequência de 59\% na família B e segregou com a mutação L338P, causadora da doença nesta família. A distribuição genotípica e alélica dos polimorfismos C2377A, A2478G e T1500C variou nos grupos deficientes e não deficientes enzimáticos, indicando que estes polimorfismos contribuíram para o fenótipo redução da atividade enzimática.

Palavras-chave: Hidroximetilbilano sintase; polimorfismos genéticos; atividade enzimática; porfiria aguda intermitente.

Tese de mestrado desenvolvida no Laboratório de Patologia Molecular do Depto. de Patologia do Hospital Universitário Antônio Pedro. Universidade Federal Fluminense (UFF) - Niterói-RJ - Brasil.

Correspondência: Ana Denise Gomes Gonzaga

Rua Marquês do Paraná, $303-4^{\circ}$ andar

Laboratório de Patologia Molecular, sala 30

24033-900 - Niterói-RJ - Brasil

Tel.: (21)2629-9043 / (21)3396-8708 - anadenise.farma@gmail.com

\section{Abstract}

The hydroxymethylbilane synthase enzyme (HMBS) catalyzes the third stage of biosynthesis of the heme. Mutations in the gene that encode this enzyme result in partial reduction of its activity, leading to acute intermittent porphyria (AIP), an inherited autosomal dominant disease. This work aimed at investigating the following genetic polymorphisms: C2377A (ApaL I), A2478G (BstN I), G1345A (Msp I) and T1500C (Pst I) in intron 1 ; A3581G (BsmA I) in intron 3 and C7064A (Hinf I), in intron 10 of the gene, which influence the phenotypic expression of the enzyme, thereby reducing its activity. Eighty blood donors and 124 members of four families with a history of AIP (Families D, $\mathrm{S}, \mathrm{B}$ and SP) were included in the study. Initially the genomic DNA was isolated from samples of whole blood by the precipitation method and the enzyme activity was evaluated in hemolysate, which was quantified by spectrophotometric and spectrofluorometric assays. The individuals were classified as enzyme impaired and non-impaired using reference values established by these methods. Families with history of AIP had had the mutation defined by PCR-SSCP and sequencing in a previous study. The genetic polymorphisms were evaluated by PCR-RFLP. Significant differences in allelic polymorphisms were identified comparing families with history of AIP and blood donors. The genotypic distributions of the C2377A, A2478G, G1345A, A3581G and C7064A polymorphisms in families with history of AIP were significantly different to those found for blood donors, indicating that these polymorphisms may be genetic markers in these families. The A allele of the C7064A polymorphism presented a frequency of $59 \%$ in Family B and was segregated with mutation L338P, the cause of the disease in this family. The genotypic and allelic distribution of the C2377A, A2478G and T1500C polymorphisms varied in the impaired and non-impaired Groups, indicating that these polymorphisms contributed to the reduction in enzymatic activity.

Key words: Hydroxymethylbilane synthase; genetic polymorphisms; enzymatic activity; acute intermittent porphyria.

Avaliação: A RBHH publica os resumos e abstracts de teses da área apresentados em entidades que tenham programas de pós-graduação reconhecidos pelo $\mathrm{MEC/Capes} \mathrm{e} \mathrm{considera} \mathrm{a} \mathrm{obtenção} \mathrm{do} \mathrm{título}$ suficiente para sua publicação na forma como se propõe a seção.

Recebido: $05 / 02 / 2009$

Aceito: 11/02/2009 